Journal of Educational Research in Developing Areas (JEREDA

Vol. 1. Issue 2, Pp. 88-99, 2020

http://www.jeredajournal.com

E-mail: info@jeredajournal.com

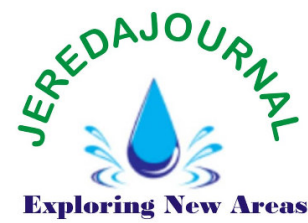

Research Article DOI: https://doi.org/10.47434/JEREDA/

eISSN : $2735-9107$

\title{
NARRATIVE STORY-TELLING IN DEVELOPING SIGNED AND WRITTEN TEXTS FOR STUDENTS WITH HEARING LOSS IN BASSA, PLATEAU STATE, NIGERIA
}

\section{Rahila Samuel Milaham}

Department of Special Education, Federal College of Education Pankshin, Plateau State, Nigeria.

Email: rahilasamuel22@gmail.com

(D) https://orcid.org/0000-0002-8518-291X

Received: $28^{\text {th }}$ August, 2020; Revised: $15^{\text {th }}$ September, 2020; Accepted: $20^{\text {th }}$ September, 2020

\section{ABSTRACT}

Introduction: Many students with hearing loss start schooling with less or no prior experiences with written or signed narratives. In the school, these students often face serious challenges using narrative-retelling to develop written text.

Purpose: The purpose of this study was to explore the students' narrative written and signed texts development. The students were encouraged through the provision of experience stories, where they were asked to tell a story from their personal experiences. The intervention was carried out for 6 weeks. This involved teaching and learning about narrative genre. Two students with hearing loss who were in their third year in junior secondary school were purposefully selected for the study.

Methodology: Qualitative design was used to understand the students' experiences and to answer the research questions that were presented. The narrative stories were both from the students' experiences and the teachers' modelled stories. The students' texts were analysed for common narrative structures such as characters, settings and events.

Results: The result indicated that most of the students were able to organise information in their written texts well. This suggests that they understood what they were writing about as seen in their written texts. They were able to classify information into main and supporting ideas. They also made connections between previous and new knowledge.

Recommendations: Based on findings of the study, it was recommended that teachers of students with hearing loss should be encouraged to use narrative-retelling for training students with hearing loss on written text development.

Keywords: Strory telling, Narrative story telling, signed text, Written text, hearing loss

\section{Cite paper as:}

Crossref Miliham, R. S. (2020). Narrative story-telling in developing signed and Cited-by written texts for students with hearing loss in Bassa, Plateau state, Nigeria. Journal of Educational Research in Developing Areas, 1 (2), 8899. https://doi.org/10.47434/JEREDA.1.2.2020.88.

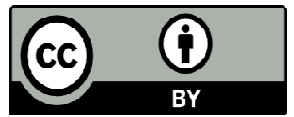

Copyright (c) 2020 The author(s) of this article retain(s) the copyright. 
Journal of Educational Research in Developing Areas (JEREDA

Vol. 1. Issue 2, Pp. 88-99, 2020

http://www.jeredajournal.com

E-mail: info@jeredajournal.com

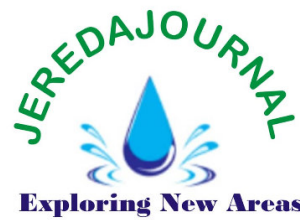

\section{PUBLIC INTEREST STATEMENT}

This study provides useful information about written text development of students with hearing loss in plateau state. Teachers of students with hearing loss will know how to teach writing to students. The results will be useful for educational planners in planning educational programmes for students with hearing loss.

\section{INTRODUCTION}

The education given to students with hearing loss is an area that requires reformation, particularly in the area of signing and writing. This problem is not peculiar to Nigeria but it is a worldwide problem (Eleweke, 2002; Babudoh, 2014). One of the ways students can be taught to write and read is through the use of narrative story telling using different genres, especially personal narratives and fictional or make-believe ones. Personal narrative is a recount of a real past experience, while a fictional narrative is either a composition or recollection of previously heard story. This study focused on personal narrative. The students were engaged in writing about their past experiences. As noted by Griffin, Hemphill, Camp and Wolf (2004), successful acquisition of literacy skills by students depends on their ability to produce narrative stories. This is because story-telling promotes diversity in opinion and skills. It encourages students to make selections of narrative forms based on anticipated audience, rather than basing the experiences to school-story format that educators often use. Morere and Allen (2012) state that students with hearing loss learn sign language in English as their first language of communication mostly in school. At home, most parents use local signs to communicate with their deaf children. This makes transition from home to school not so smooth to the children in terms of writing or reading. It also impedes the children's access to written instructions that can help to address the signing and writing challenges.

A study by Mitchell and Karchmer (2004) discovered that a small percentage of students with hearing loss acquire American Sign Language (ASL) naturally at home while majority of them do not have sufficient access to either English nor ASL during their early developmental stage. This according to the researchers can lead to delay in both languages which can affect their ability to write and read and consequently affect their performances in school. Most students with hearing loss are enrolled in schools with poor knowledge and experiences in sign language as well as printed symbols. These students either have limited or no experiences at all in signs and prints which they can transfer into written form. These negatively affect their ability to write meaningfully. Milaham (2020) states that many students with hearing impairment have fewer or no experiences with story-telling as they are born deaf and in some cases by hearing parents who themselves cannot sign using ASL. In school, many students often express themselves using their local sign languages, they often find it difficult to communicate such experiences using printed symbols and to other people who cannot speak their language. That is why on entering school for the first time, many of them have challenges of how to sign to tell story and write such story down for others to read. It is based on these challenges that this study is being carried out.

Sign language is a natural language that is based on visual-manual modality (Boudreault \& Mayberry 2006). It is as complex as any other speech language. However, like spoken language, sign language is not a global language. Signed languages around the world are as dissimilar as, English, Greek, German and Japanese (Stokoe, Armstrong, Karchmer, \& Van Cleve 2002). These are all different in the way individual sign and structures of signed sentences are constructed. Sign language is not a substitute of speech language and not a signed version of a speech language either. It stands on its own independently. American Sign Language and Australia Sign Language for instance are not signed versions of English, 
Journal of Educational Research in Developing Areas (JEREDA

Vol. 1. Issue 2, Pp. 88-99, 2020

http://www.jeredajournal.com

E-mail: info@jeredajournal.com

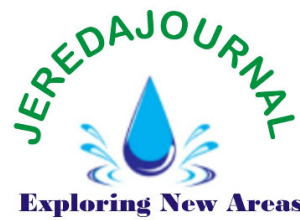

neither are they based on English. In addition, sign language is not made up of a standardized system of gestures. Many linguistic studies have shown that signed languages have their own grammatical rules, syntax, phonology, morphology and other linguistic features like spoken languages (Schlenker, 2020). Sign language can be considered as a real language comparable to any spoken language in its complexity and allows for unlimited variety of sentences to be constructed. As spoken language is being used for expression, so also sign language can be used to do the same. However, sign language can be signed in English in formal settings using English grammatical structure. Finger spelling is another variant that can be used in a formal setting. This means the complete spelling of letters of the alphabet via a manual code.

The study was hinged on sociocultural theories of teaching and learning developed by Vygotsky in 1980. This theory states that learning is manifested as a result of interactions which occur during mediated and social activities. The theory is also based on the fact that human beings' thinking takes place in a cultural setting, which is mediated by language (Vygotsky, 1980). As the teachers prompted the students with stories and pictures, the students capture the idea in their language zone. Cognitive development, according to Vygotsky (1980), evolves through social interactions that guide learning within the Zone of Proximal Development (ZPD). A socio-cultural approach was chosen for this study because it is the starting point to understand how students acquire social and cultural knowledge and experiences in preparation for literacy development. Socio-cultural theory centred on understanding the contexts, learning environments, social interactions and cultural practices that can best be used to develop literacy competence. Socio-cultural perspectives on literacy are based on issues of equity and diversity, which provide a rationale for "second chance" opportunities for students who have difficulties with writing. Writing is a cognitive process that involves

comprehension of ideas, expressive language and mechanical skills (Dorn \& Soffos 2001). It is not a skill that just develops in a particular stage; rather, it has its beginning in the early stages of life. It evolves from pre-speech gestures children make from the language they hear and later use. The children realize that spoken or signed words can be represented in print. Writing is a communicative activity that can be encouraged and nurtured during language development stages of a child. Writing develops from language students hear and use.

However, students who have no access to language would therefore have problems in using language to communicate through writing (Anita, Kreimeyer \& Reed, 2005). This is because such students cannot hear and understand the language rules. Rass, (2001) states that during writing, they show serious challenges with the content, organization, purpose, targeted audience, vocabulary use and mechanics such as punctuation, spelling and capitalization. Writing according to Hugley (1983) is a communicative act which depends on awareness of social expectation within the learners' social environment. This means that writing develops the writer's social relationship and social expectation because it is one of the tools in communication.

Furthermore, writing is an essential aspect of interaction and of language teaching beside reading and speaking. Graham and Harris (2002) state that students use written text to express their ideas, opinions and views. Such method of communication is extremely important in this print-oriented modern world, where writing is unavoidable. Myles (2002) expresses that the ability to write is not a naturally acquired skill; it is usually learned or culturally acquired as a set of practices in formal settings. Writing skills is acquired through practices and learned through experiences, where the learners put their experiences and thinking down in print to describe their feelings. However, most students with hearing loss exhibit difficulties in writing (Rosen, Hartman \& 
Journal of Educational Research in Developing Areas (JEREDA

Vol. 1. Issue 2, Pp. 88-99, 2020

http://www.jeredajournal.com

E-mail: info@jeredajournal.com

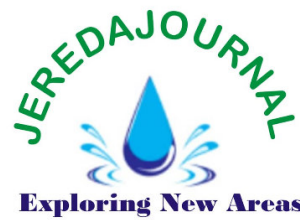

Wang, 2017). Mayer (2010) argues that writing difficulties are caused primarily by the nature of the writing system that students with hearing loss are taught to use. This system is based on the alphabetic system of phonemes because phonemes are grounded in audition where students with hearing loss always have problem using the phonemes. Students with hearing loss cannot successfully use phonemes to write and therefore cannot clearly express their thoughts. Rosen, Hartman and Wang (2017) note that students with hearing loss demonstrate significant delay in writing when compared with hearing peers. According to them, deaf students do not use cohesion devices to write as their hearing counterparts.

The challenges students with hearing loss face when writing in English is because they do not have full auditory access to phonological and morphological aspects of English syntactic and organization. Williams and Mayer (2015) carried out an integrative review of research on writing development, instruction, and assessment of young deaf children in preschool through third grade. They reviewed 17 studies published between 1990 and 2012 and found an overemphasis in research on spelling development and word use in deaf children's writing. They also found that few researches have been done on instruction and assessment of students with writing difficulty.

Effective development of language, whether signed or written depends on the hearing family members' ability to respond to their deaf children's communication and auditory needs (Caselli \& Volterra, 1990). To understand communication and auditory needs of a deaf child, Van Staden, Ridge and Badenhorst (2009) expressed that the teacher should observe the families' communication preference, the deaf child's communication needs and capabilities, availability and accessibility of language to the child. Communication options for the deaf children according to Easterbrooks and Huston (2008) include manual communication, oral communication or a combination of both.

However, families of deaf children always find auditory communication very frustrating because they have to learn Sign Language in order to communicate with their children. This makes these children to be deprived of participating in activities of the school and experience social stigma and prejudice.

There are numerous benefits of stories in teaching and development of narrative genre to students with hearing loss (SWHL). Stories assist students to develop vocabulary that can be used in written text. Stories deepen students' understandings of words especially, if they are allowed to write from their own prior knowledge. Walters (2006) expressed that stories help to promote students' retention of words because they were actively engaged in development of the stories both with their peers and teachers. Al-Dersi (2013) observed that in order to really understand a word, the word must be known to them to be able to use it in their written text. Stories also help to stimulate students' curiosity and language acquisition hence they can repeat the words unconsciously in various forms. Reading stories to students according to Waring (2001) does not only offer the opportunities to revisit words learned, but also to understand and use them in real life communication which guarantees longer retention of such vocabulary.

\section{STATEMENT OF THE PROBLEM}

Learning to write is a serious challenge to all students with hearing loss, especially development or text creation. These challenges could be due to lack of language of instruction. In schools, these students sometimes find themselves under teachers who themselves have no knowledge of ASL to teach it to the students for the purpose of communication. Singleton, Morgan, DiGello, Wiles and Rivers (2004) observed that many students with hearing loss in upper primary school do not have sufficient knowledge of ASL during their early days in school. As noted by Akinyeye (2015), 90\% of students in public secondary schools 
Journal of Educational Research in Developing Areas (JEREDA

Vol. 1. Issue 2, Pp. 88-99, 2020

http://www.jeredajournal.com

E-mail: info@jeredajournal.com

generally, especially at the junior school level in Nigeria cannot read and write. Babalola (2012) added that in Nigerian schools, most teachers use inappropriate teaching instruction to teach writing to students. Also reported by Oyetunde (2009) that during reading, students are usually asked to "read after" the teacher letters or passages from a textbook without seeing the printed symbols

In addition, many teachers are not aware of the extent to which storytelling can effectively be used with students with hearing loss. Other teachers see storytelling as mere entertainment rather than a process of transmitting knowledge. Such teachers see story telling as taking too much of their instructional time in the class. These create gaps that need to be filled by teachers to promote the signing and writing needs of the students. The current study was carried out to determine how stories can be used to develop the students' narrative written text. Students with hearing loss were prompted with stories to motivate them towards the development of narrative written text which was based on their personal experiences.

\section{PURPOSE OF THE STUDY}

The purpose of this study was to explore junior secondary school three (JSS3) students' narrative written text development. Specifically, the study seeks to:

1. explore the extent to which narrative story telling develop writing text of students with hearing impairment;

2. determine the extent to which narrative story telling develop signing texts to students with hearing loss.

\section{RESEARCH QUESTIONS}

Two research questions were set to guide the study:

1. To what extent does narrative story telling develop the writing texts of students with hearing loss?

2. To what extent does narrative story telling develop the signing

texts of students with hearing loss?

\section{HYPOTHESIS}

The following hypotheses were formulated and tested during the research.

1. narrative story telling does not assist students with hearing loss to develop written texts in Plateau State.

2. narrative story telling does not assist students with hearing loss to develop signed texts in Plateau state.

\section{METHODOLOGY \\ Research Design}

The research design adopted for this study was a qualitative design. This research design was chosen because it recognises the complexity of experiences and the value of human interaction. The use of qualitative approach was also to understand the students' experiences and enable the researcher answer the research questions that were presented in the study.

\section{Population \& Sample}

Convenience sampling was used to select the school and class for the study. In convenience sampling, researchers use their judgement to select the participants based on the students' background knowledge and experiences relevant to the study. The population of this study consisted of all the six Junior Secondary School three (JSS3) students with hearing loss in school for the deaf Bassa Plateau state. The choice of one class is in line with the case study approach. JSS3 students were chosen based on the fact that they are in the middle class and should have a foundation for further writing practices. Furthermore, they were also chosen on the basis that they had been exposed to sign language and taught using sign language in JSS1, in their previous year. Therefore, it was expected that the students should be able to express themselves through signing.

Sample of two students were selected, the students selected were 
Journal of Educational Research in Developing Areas (JEREDA

Vol. 1. Issue 2, Pp. 88-99, 2020

http://www.jeredajournal.com

E-mail: info@jeredajournal.com

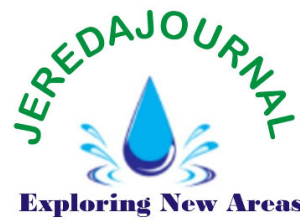

Nalong and Ibrahim. The two students were with various degrees of hearing loss profound to severe hearing loss base on their anecdotal record. The students were selected through convenience sampling technique based on their general low performance in their Junior Secondary Certificate Examination (JSCE), which was meant to qualify them for Senior Secondary Education. They were also selected based on the assumption that their written text could improve after the intervention. This relates to Tedla and Negassa (2019) study that also discovered that students with hearing loss perform poorly academically. Their two English teachers who voluntarily agreed to be part of this study were also participants in the study. The choice of the teachers was based on the fact that they had been teaching reading and writing to students in the school using ASL for years. The teachers were also interviewed to understand how they use narrative genre to teach writing.

\section{Method of data collection}

Data was collected using narrative genre. Case study was employed in the data collection process to observe the participants in their classroom where academic activities took place. This was done to understand how students with hearing loss interact with text and how Language Experience Approach (LEA) could be used to develop their literacy skills. The use of case study allowed the researcher to use different methods of data collection to get information from the participants through observing their written documents, interviewing and describing their actions. The teachers asked the students questions about stories they have heard. The teachers also signed some narrative stories to the students and asked them questions about characters in the stories. This was done to scaffold the students to sign their own narrative stories taking note of the characters. The questions asked helped to activate the students' thinking processes. They were asked to draw picture of the story or rewrite the story. The story was expected to be based on

content, organisation and sentence structures.

\section{Procedure for data collection}

The students were guided to sign and write their texts based on experiences from places they have visited, either at home, school or in social gathering. This narrative form of writing is based on Wood (2017) idea, which centred on participants' live experiences and interpretations of such experiences. The participants' real names were replaced with pseudonyms to protect their identities. The two teachers served as participants in the study. They engaged the students in story-telling and discussion about what to write. This was done to motivate the students in the writing process and to find out their preknowledge (Oyetunde, 2009; Andzayi \& Umolu, 2004). During the signing session, the teacher stood in front of the class so that all the students could see the signs.

However, before the students started to write their stories, they were given time to practise how to sign the stories several times in groups. They were also engaged in discussing the main ideas from the stories. After the students had finished practise-signing their stories, they were asked to write them down in their exercise books. The teachers gave them guided questions to scaffold their narrative writing. These questions were from the narrative story read to them. They could also use their experiences from home to write their text.

\section{Instrument for Data Collection}

The instrument used for data collection was students' written text, observation, and unstructured interview. To ascertain the validity of the instrument, it was given to two experts in the field of special education in university of Jos, department of special education, Plateau state, Nigeria. For reliability, it was administered on samples of students selected from the school for the deaf, Bassa Plateau state Nigeria.

\section{Procedure of Data Analysis}

Volume 1, Number 2

93 | Page 
Journal of Educational Research in Developing Areas (JEREDA

Vol. 1. Issue 2, Pp. 88-99, 2020

http://www.jeredajournal.com

E-mail: info@jeredajournal.com

Permission from the Director of Education in Plateau State Nigeria, this was given to allow me to carry out the research in the school. Similarly, I also received permission from the principal of the school where the study was to be conducted. Consent forms were given to all the participants, namely the two English teachers and the JSS3 students mentioned earlier. Consent of parents and guardians of the students' participants was also sought. They all signed the consent form, consented to participate in the study and to be videotaped.

\section{Method(s) of Data Analysis}

The data collected was analysed based on the research questions of the study. In accordance with identification principles of qualitative research and phenomenology, the researcher analyzed the data, focused on main idea in each participant's experience and reported the data in as much detail as possible. The researcher carefully and thoroughly reviewed each student's texts in order to pull out any major themes or specific factors that played a role in the written text development of the students. The students' transcripts were reviewed several times to ensure that all relevant or important themes were captured and all possible implications were explored. We also analyzed each student's text and the teacher's interview individually for deeper understanding of common factors that influenced students' written text.

Analysis of narratives helped in exploring the features in the students' written texts and common narrative structure used such as; characters, setting, events and solution. Structure of the narratives include; abstract, orientation, complicating action, evaluation, resolution and coda. However, it is not necessary for all the six to be present in every narrative.

\section{RESULTS AND DISCUSSIONS}

The results were organized in accordance with the hypotheses as follow:

1. narrative story telling does not assist students with hearing loss

to develop written texts in Plateau State.

2. narrative story telling does not assist students with hearing loss to develop signed texts in Plateau state.

For the narrative writing, the following procedure was used. It started with a class discussion where the teacher read two narrative texts to the students. The students were asked to write summary of the text that was read by the teacher. Thereafter, a student was asked to read the summarised text out. The students were encouraged to construct their own stories to sign to the class.

One day mother send me to market to buy fish. I saw my friends for me I call them to wait for me. We walked together. I remember I have money let me check. I check I no see the money. I go back I found only $\mathrm{N500}$ and my mother give me N1000.00. We go to market with my friends I bought some things and my friends say I buy moimoi for us with the money

Figure1: Nalong's signed text

\section{Topic: Blessing and friends}

One day, my mummy send me to market to buy fish for food $i$ was working and $i$ saw two of my friend wakling and i called them and the wait for me $i$ was busy running $i$ went and meet them we were walking together and talking together something told me that i should looked at my hand $i$ did not see the money $i$ told my friends i will go back and look. for the money the were laughing. i ran back and saw the money it was not complete $i$ search for it $i$ did not see it. $i$ went and meet them we went to the market and $i$ ask the fish it was five hundred and my mummy gave me $\mathrm{N} 1000$ i said thank God $i$ buy everything and my friend told me to buy moimoi for use went to the shop $i$ bought 3, moimoi of us. we finish and $i$ bought orange hundred own. I came back home, $i$ told my mother that no change for her she said $i$ should tell the truth $i$ told her the truth then she agree at the end.

Figure 2 : Nalong's written text 
The figures above show Nalong's signed and written texts. Her text was transcribed verbatim as she signed it. Nalong wrote about Blessing and her friend. Nalon gused her written text as way to communicate with her peers and teacher. The characters in both Nalong signed and written texts are "mother", "friends" and "herself" (referred to by the pronoun "I"). The setting is a market. Nalong's signed and written texts were based on her daily life experience. Nalong showed how her daily life experience shaped her knowledge. She used the knowledge gained to express herself in signs and prints. Gökler, Özay, Öztas and Öztas (2006) state that experiences can be acquired through listening, watching television, parents' talk or from the Internet, especially for students living in urban areas. Nalong's narrative story reflects her socio-cultural knowledge and her experience of going to the market. Nalong wrote, "I came back home, i told my mother that no change for her she said $i$ should tell the truth $i$ told her the truth then she agrees at the end". In Nalong's text, she was able to logically organise her information in both her signed and written texts. She stated the topic and moved on to the introduction, body and conclusion as seen in her text. Nalong used her prior knowledge as her starting point for her signed and written texts.

My friend for school, we go home I am put his shoe. We go m-a-r-k-e-t with friend. Me have friends girls too we are go home eat food

Figure 3: Ibrahim's signed text

(1) my best friend to in school for so
home to going
(2) I am school for we shoe
(3) my best to school we going market
(4) we frend father are sugar
(5) my best frend to girls and school
(6) we going home food school
(7) my best friend to feel

Figure 4: Ibrahim's written text
The figures above show Ibrahim's signed and written texts.

From Ibrahim's signed and written text, it shows that he loves and is happy with his friend. Ibrahim's text was transcribed verbatim as he wrote it. The characters in Ibrahim's signed and written texts are "friend", "father", "girl" and himself (referred to as "I"). Although Ibrahim has fewer words in his signed text than his written text, his text suggests that he was connected to his friend and that the story was told in a real-life context. Ibrahim narrated his real relationship with his friend and not a fictional story.

Ibrahim's text suggests that his narrative is based on his situated school experiences and context. He also relates his experiences with other contexts, such as the market and his home. His written text was about what he did with his school friends. His narration suggests that he stays close to his friends at home, which is why they always go to the market and home from school together and even ate together. Ibrahim also mentioned that they went to the market with his friend but did not mention what they did in the market. Ibrahim wrote, "my best to school we going market" and "we friend father are sugar". This shows his attempt to connect with the example the teacher modelled during the scaffolding session.

After the analysis, the findings indicated that the students were able to contextualize event with signs. They used vocabulary mostly from events perspective in signing their narratives stories. The students, after being engaged in discussion gave examples of the genre from which they derived the components of the story from, such as character and events. As seen in their texts, Nalong included character and events in her text, while Ibrahim missed one of these structures or the other. In general, their narrative written texts were better developed after the intervention. They were able to tell story from past experiences. This result is not new as researchers like Herrera Fernandez (2019) and Farina, Morrell and Banerjee (2017) have reported similar 
Journal of Educational Research in Developing Areas (JEREDA

Vol. 1. Issue 2, Pp. 88-99, 2020

http://www.jeredajournal.com

E-mail: info@jeredajournal.com

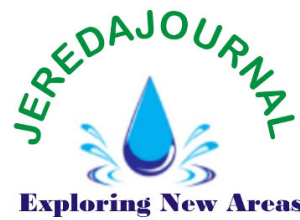

results concerning signed and written expression of children with hearing loss. Contrary to the findings of this study, Rusell (2016) had earlier reported that students with hearing loss tend to perform poorly in writing. As the student - participants in this study are in their early stages of learning to write, the result could be a direct assumption that they might perform poorly in text construction.

Narrative genre was introduced in the classroom. It started with an instructional discussion in which the researcher prepared for the learning process through asking the students questions about the stories. The researcher also signed the narrative stories. She scaffolds the students' learning by re-signing through questioning their narrative stories, stating the character and structure of their texts. The questions activated the students' thinking processes and helped them to base their answers on their texts. In this study, the narrative story telling focused on content with the structure explicitly taught to them by the researcher. Qualitative data was used to illustrate the students' accuracy and fluency in the signed and written text. Though some of the students' statements were unclear, the intervention seems to inform their English knowledge and competence in construction of the text. More importantly, the students signed and wrote their texts independently. The researcher gave the students freedom to develop their individual signed and written texts. The intervention went on with the students in the school for four (4) week. At the end, the students were able to sign using ASL. They were able to produce their signed and written texts. The students increased in their ability to use English language to express themselves though with some grammatical mistakes as seen from their texts.

As observed during their class interaction with their teachers using ASL, the students were motivated to participate in the construction of their signed and written texts. The story provided an "entry point" into the signed

and written texts that were available to them before. They were deeply involved in generating ideas for their text. Most importantly, the researcher gave the students time to express themselves. Throughout the intervention period, the students' activities were based in their socio-cultural environment. The language of instruction was ASL using English language.

\section{CONCLUSION}

This study focused on how students with hearing loss use writing to demonstrate their understanding of different genres of writing in English. The students were engaged in interaction through discussion of signed and written stories. They were guided to identify the structure, ideas and characters in the individual story. Vygotsky's socio-cultural theory was employed, where the students were made to use their experiential background to construct the written text. In addition, the juxtaposition of written texts gave insights on how zone of proximal development and role of a knowledgeable person can help students to learn to write. Narrative story was considered as good resources for language teaching and storytelling and was used as guide for students to write their own texts. It helped them understand written stories easily. Their confidence in the use of English was boosted within a short period of time. Story-telling gave the students opportunity to be friendly with peers and share personal experiences This suggests that stories should be given preference when teaching signed and written texts to students with hearing loss. Generally, retelling stories are powerful tools for promoting vocabulary development of students with hearing loss.

\section{RECOMMENDATIONS}

Based on the findings, the following recommendation was made that:

1. Students with hearing loss should be extensively trained on narrative-retelling. This will improve their ability to express 
Journal of Educational Research in Developing Areas (JEREDA

Vol. 1. Issue 2, Pp. 88-99, 2020

http://www.jeredajournal.com

E-mail: info@jeredajournal.com

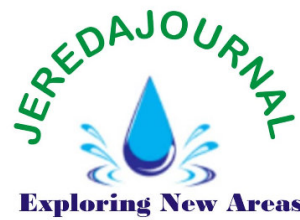

themselves meaningfully using signed and written texts

2. Teachers teaching students with hearing loss should be regularly scheduled for workshops and seminars that are based on methods and strategies for teachers who teach students with hearing loss.

3. Teachers, especially those who have no background knowledge about ASL and special education should be trained on how to communicate and identify the causes and characteristics of not only pupils with writing difficulties but also those with reading difficulties as the two cannot be treated in isolation

\section{Conflicts of Interest:}

The author declares no conflict of interest.

\section{Acknowledgments:}

The researchers acknowledged the Director of Education and the Principal, staff and students of the School for the Deaf, Bassa in Nigeria, where the study was carried out for allowing me to conduct the study in the school. Your willingness to participate in the study is highly appreciated. My thanks go to the parents of students with hearing loss who gave me their permission to engage their children in the research. I am also grateful to the students who wrote their stories and showed interest at every point of the data collection.

\section{Notes on Author}

Rahila Samuel Milaham is a senior Lecturer in the Department of Special Education, Federal College of Education Pankshin Plateau state. Her area of research interest is Deaf Education.

\section{Disclaimer Statement}

I hereby declare that this paper is my own and autonomous work. Part of the article has been written from the PhD thesis work. All texts either quoted directly or paraphrased have been indicated by in-text citations.

\section{REFERENCES}

Al-Dersi, Z. E. M. (2013). The use of short-stories for developing vocabulary of EFL learners. International Journal of English Language \& Translation Studies, $1(1), 72-86$.

Andzayi, C. A., \& Umolu, J. (2004). Reading instruction in primary \& secondary schools. University of Jos.

Antia, S. D., Reed, S., \& Kreimeyer, K. H. (2005). Written language of deaf and hard-of-hearing students in public schools. Journal of Deaf Studies and Deaf Education, 10(3), 244-255.

Babudoh, G. B. (2014). Enhancing literacy skills of students with congenital and profound hearing impairment in Nigeria using Babudoh's comprehension therapy. Journal of the International Association of Special Education, 15(1), 23 - 33.

Boudreault, P., and Mayberry, R. I. (2006). Grammatical processing in American sign language: age of first-language acquisition effects in relation to syntactic structure. Lang. Cogn. Process. 21, 608-635. doi: $10.1080 / 01690960500139363$

Caselli, M. C., \& Volterra, V. (1990). From communication to language in hearing and deaf children From gesture to language in hearing and deaf children (pp. 263-277): Springer.

Dorn, L. J., \& Soffos, C. (2001). Scaffolding young writers: $A$ writer's workshop approach: Stenhouse Publishers.

Easterbrooks, S. R., \& Huston, S. G. (2008). The signed reading fluency of Students who are Deaf/Hard of Hearing. Journal of Deaf studies and Deaf Education, 13(1), 37-54.

Eleweke, C. J. (2002). A review of issues in deaf education under Nigeria's 6-3-3-4 education system. Journal of Deaf Studies and Deaf Education, 7(1), 74-82. 
Journal of Educational Research in Developing Areas (JEREDA

Vol. 1. Issue 2, Pp. 88-99, 2020

http://www.jeredajournal.com

E-mail: info@jeredajournal.com

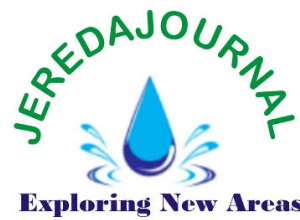

Farina, N., Morrell, L., \& Banerjee, S. (2017). What is the therapeutic value of antidepressants in dementia? A narrative review. Intenational Journal of Geriatric Psychiatry, 32(1), 32-49.

Gökler, F., Özay, E., Öztas, F., \& Öztas, H. (2006). The improvement of ecology teaching in secondary school: effects of concept maps in the restructuring of previous knowledge. Journal of Science Education, 7(2), 115-118.

Graham, S., \& Harris, K. R. (2002). Prevention and Intervention for Struggling Writers.

Griffin, T. M., Hemphill, L., Camp, L., \& Wolf, D. P. (2004). Oral discourse in the preschool years and later literacy skills. First language, 24(2), 123-147.

Harmon, J. M., Hedrick, W. B., \& Wood, K. D. (2005). Research on vocabulary instruction in the content areas: Implications for struggling readers. Reading \& Writing Quarterly, 21(3), 261280.

Herrera Fernandez, D. R. (2019). Spanish as a foreign language and digital storytelling: an intercultural approach. Sosyal Bilimler Enstitüsü.

Hugley, M. (1983). Basic writing for the middle school students. PrenticeHall, Inc.

Mayer, C. (2010). The demands of writing and the deaf writer. In M. Marschark \& P. Spencer (Eds.), Oxford handbook of deaf studies, language, and education, (2nd Ed.), (pp144-155). New York: Oxford University Press.

Milaham, R.S (2020) writing and signing to develop written genres: a study of Nigerian Hearing-loss students' writing (Doctoral Dissertation, Nelson Mandela University (South Africa). unpublished

Mitchell, R. E., \& Karchmer, M. (2004). Chasing the mythical ten percent: Parental hearing status of deaf and hard of hearing students in the United States. Sign language studies, 4(2), 138-163.

Morere, D., \& Allen, T. (2012). Assessing literacy in deaf individuals: Neurocognitive measurement and predictors: Springer Science \& Business Media.

Myles, J. (2002). Second language writing and research: The writing process and error analysis in student texts. Tes/-Ej, 6(2), 1-20.

Oyetunde, T. (2009). Beginning reading scheme empowering teachers to help their pupils become good teachers. Jos: LECAPS publishers.

Rass, R. A. (2001). Integrating reading and writing for effective language teaching. Paper presented at the English Teaching Forum.

Rosen, R. S., Hartman, M. C., \& Wang, Y. (2017). Thinking-for-writing" A porolegomenon on writing signed languages. American Annals of the Deaf, 161(5), 528-536.

Rusell, GS (2016). Deaf writing. A methodological proposal to work on syntax and vocabulary from the perspective of Spanish as a second and foreign language (Doctoral dissertation, Universidad Complutense de Madrid).

Schlenker, P. (2020). Gestural grammar. Natural Language \& Linguistic Theory, 1-50.

Singleton, J. L., Morgan, D., DiGello, E., Wiles, J., \& Rivers, R. (2004). Vocabulary use by low, moderate, and high ASL-proficient writers compared to hearing ESL and monolingual speakers. Journal of deaf studies and deaf education, 9(1), 86-103.

Stokoe, W. C., Armstrong, D. F., Karchmer, M. A., \& Van Cleve, J. V. (2002). The study of signed languages: Essays in honor of William C. Stokoe. Gallaudet University Press.

Tedla, T., \& Negassa, D. (2019). The Inclusive education for deaf children in primary, secondary and preparatory schools in gondar, Ethiopia. Jurnal Humaniora, 31(2), 177-187.

Van Staden, A., Ridge, E., \& Badenhorst, G. (2009). The benefits of sign 
Journal of Educational Research in Developing Areas (JEREDA

Vol. 1. Issue 2, Pp. 88-99, 2020

http://www.jeredajournal.com

E-mail: info@jeredajournal.com

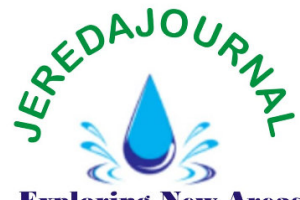

language for deaf learners with

language challenges. Per Linguam: a Journal of Language Learning $=$ Per Linguam: Tydskrif vir Taalaanleer, 25(1), 44-60.

Vygotsky, L. S. (1980). Mind in society: The development of higher psychological processes. Harvard university press.

Walters, W. W. (2006). Writing the diaspora in black international literature'with wider hope in some more benign fluid...': Diaspora Consciousness and literary expression. Diasporic Africa: A Reader, 271-289.

Waring, H. Z. (2001). Balancing the competing interests in seminar discussion: Peer referencing and asserting vulnerability. Issues in Applied Linguistics, 12(1), 29-50.

Williams, C., \& Mayer, C. (2015). Writing in young deaf children. Review of Educational Research, 85(4), 630666.

Wood, W. (2017). Habit in personality and social psychology. Personality and Social Psychology Review, 21(4), 389-403. 